\title{
PELAKSANAAN PENGADAAN BUKU TEKS PELAJARAN KURIKU- LUM 2013 DI KABUPATEN NATUNA
}

\section{IMPLEMENTATION OF THE PROCUREMENT OF 2013 CURRICULUM TEXT BOOK IN NATUNA DISTRICT}

\author{
Lisna Suliar Sari \\ Pusat Penelitian Kebijakan Pendidikan dan Kebudayaan, \\ Kementerian Pendidikan dan Kebudayaan \\ e-mail: lisna_ss@yahoo.com
}

\begin{abstract}
ABSTRAK
Tujuan dari penelitian ini yaitu untuk menganalisa mekanisme pengadaan buku teks pelajaran kurikulum 2013 dan kendalanya serta sumber pendanaan di Kabupaten Natuna. Pendekatan yang digunakan dalam penelitian ini yaitu kualitatif deskriptif. Temuan penelitian ini yaitu: 1) Pengadaan buku teks pelajaran kurikulum 2013 di Kabupaten Natuna menggunakan dua mekanisme, yaitu e-katalog dan buku sekolah elektronik; 2) Kendala mekanisme tersebut yaitu (a) menyulitkan sekolah-sekolah yang ada di Kabupaten Natuna, karena banyak penyedia/ penerbit yang tidak bersedia menyediakan buku teks pelajaran kurikulum 2013 disebabkan biaya pengiriman buku teks pelajaran cukup mahal karena harus menggunakan pesawat terbang; (b) Tidak semua sekolah di Kabupaten Natuna memiliki jaringan internet dan jika sekolah-sekolah membeli buku teks di distributor harga buku teks yang ditawarkan oleh distributor melebihi harga eceran tertinggi yang sudah ditetapkan Kementerian Pendidikan dan Kebudayaan berdasarkan zona; dan (c) pengiriman buku teks tidak tepat waktu, akibatnya pembelajaran pada semester 1 tidak menggunakan buku teks pelajaran kurikulum 2013;3) Pembelian buku teks pelajaran kurikulum 2013 menggunakan dana bantuan operasional sekolah sehingga tidak semua sekolah dapat membeli buku teks sesuai jumlah siswa yang ada disebabkan jumlah dana BOS tidak mencukupi. Studi ini disimpulkan bahwa mekanisme pengadaan buku teks pelajaran kurikulum 2013 tidak efektif dan efisien karena sekolahsekolah di Kabupaten Natuna tidak dapat menggunakan buku teks pelajaran kurikulum 2013 tepat waktu pada tahun ajaran baru dan biaya mahal.
\end{abstract}

Kata kunci: mekanisme, pengadaan buku teks pelajaran kurikulum 2013.

\section{ABSTRACT}

The purpose of this study is to analyze the mechanism for the procurement of 2013 curriculum textbooks and the constraints and funding sources in Natuna Districts. The approach used in this study is descriptive qualitative. The findings of this study are 1) The procurement of 2013 curriculum textbooks in Natuna Districts used two mechanisms, namely e-catalog and Electronic School Books; 2) the constraints of the mechanism were (a) many providers/ publishers were not willing to provide 2013 curriculum textbooks because the cost of sending textbook was quite expensive, they had to use airplanes. That was complicated for school in Natuna District; b) Not all school in Natuna Districts had an internet network and if schools bought textbooks at distributors the price of textbooks offered by distributors exceeded the highest retail prices set by zone by the Ministry of Education and Culture; and c) The delivery of textbooks was not on time, as a consequences the learning process in semester 1 did not 
use curriculum 2013 textbooks; 3) the purchase of 2013 curriculum textbooks used school operational assistance funds, so that not all schools can buy teksbooks according to the number of students avalaible due to insuffucient BOS funds. The study concluded that the mechanism for the procurement of 2013 curriculum textbooks was ineffective and inefficient because schools in Natuna Districts were unable to use 2013 curriculum textbooks on time in the new school year and had to expend a higher cost.

Keywords: mechanism, procurement of the 2013 curriculum textbooks.

\section{PENDAHULUAN}

Buku teks pelajaran merupakan salah satu perangkat yang penting dan sebagai sumber belajar utama yang digunakan dalam kegiatan pembelajaran. Buku teks pelajaran menjadi salah satu alat yang digunakan guru maupun siswa sebagai sumber belajar, karena akan memudahkan guru dalam mentransfer ilmu pengetahuan, norma-norma agama, nilai-nilai kehidupan, budaya, seni, dan wawasan lainnya kepada siswa. Manfaat buku teks pelajaran bagi siswa, yaitu sebagai pedoman manual yang efektif dalam belajar, sehingga siswa akan lebih mudah memahami pembelajaran dengan sesuatu yang konkrit (nyata) melalui media belajar. Hal tersebut sejalan dengan yang di jelaskan oleh Chambliss dan Calfee (1998 dalan Suratni dan Jimmy Paat, 2014) bahwa buku teks pelajaran adalah alat bantu siswa untuk memahami dan belajar dari halhal yang dibacanya serta memahami dunia (di luar dirinya).

Dalam Peraturan Menteri Pendidikan dan Kebudayaan (Permendikbud) Nomor 8 Tahun 2016, tentang Buku Yang Digunakan Oleh Satuan Pendidikan, dijelaskan bahwa buku terbagi menjadi 2, yaitu buku teks pelajaran dan buku non teks pelajaran. Buku teks pelajaran ialah sumber pembelajaran utama untuk mencapai kompetensi dasar dan kompetensi inti dan dinyatakan layak oleh Kementerian Pendidikan dan Kebudayaan
untukdigunakanpadasatuanpendidikan.Buku non teks pelajaran, adalah buku pengayaan untuk mendukung proses pembelajaran pada setiap jenjang pendidikan dan jenis buku lain yang tersedia di perpustakaan sekolah.

Undang-Undang Nomor 3 Tahun 2017 tentang sistem perbukuan menyatakan bahwa, buku teks harus memuat materi pembelajaran dalam rangka peningkatan keimanan, ketakwaan, akhlak mulia, dan kepribadian, penguasaan ilmu pengetahuan, dan teknologi, kepekaan, kemampuan estestis, kemampuan kinestestis dan kesehatan, serta pemahaman nilai-nilai Pancasila sebagai dasar negara yang disusun berdasarkan standar nasional pendidikan (SNP). Buku teks utama meliputi buku mata pelajaran pendidikan agama, matematika, Ilmu Pengetahuan Alam (IPA), Ilmu Pengetahuan Sosial (IPS), Bahasa Indonesia, Bahasa Inggris, Keterampilan, Seni Budaya, serta Pendidikan Pancasila dan Kewarganegaraan (PPKn).

Hasil laporan World Bank (1989, dalam Efendi, Anwar, 2009) menunjukkan bahwa di Indonesia tingkat siswa memiliki buku dan fasilitas lainnya berkorelasi dengan prestasi belajarnya. Hasil temuan Supriadi (1997, dalam Efendi Anwar, 2009), juga menyatakan bahwa tingkat siswa memiliki buku berkorelasi positif dan bermakna terhadap prestasi belajar siswa. Artinya bahwa buku teks pelajaran memegang peranan penting 
dalam peningkatan prestasi siswa. Oleh sebab itu setiap siswa harus memiliki buku teks pelajaran dalam kegiatan pembelajaran di sekolah maupun di rumah.

Menurut Bambang Subdibyo dalam Kompas (2008), permasalahan buku teks pelajaran sebagai sumber belajar sangat kompleks, karena belum semua buku teks pelajaran telah memenuhi syarat kelayakan untuk terbit, mahalnya harga buku teks pelajaran yang disebabkan mahalnya biaya pencetakan buku, harga kertas, biaya distribusi, besarnya margin keuntungan penerbit, dan adanya kolusi antara penerbit dengan pihak sekolah. Selain itu, buku teks yang ditetapkan sekolah tiap tahun berganti dan adanya pihak sekolah yang mewajibkan siswa untuk membeli buku teks pelajaran di sekolah atau koperasi sekolah. Hal lainnya adalah anggaran dana bantuan operasional sekolah (BOS) yang terbatas untuk penyediaan buku teks pelajaran bagi siswa di sekolah.

Oleh sebab itu, untuk mengatasi permasalahan tersebut dan mempermudah sekolah menyediakan buku teks pelajaran kurikulum 2013 yang bermutu, merata, dan murah, serta sesuai dengan Standar Nasional Pendidikan (SNP), Pemerintah melalui Kementerian Pendidikan dan Kebudayaan pada tahun 2008 menggulirkan buku sekolah elektronik (BSE). Sekolah diperbolehkan memilih buku yang diperlukan dan mengunduhnya (download), mengkopi, dan menggandakan buku-buku teks pelajaran tersebut sesuai kebutuhan.

Pengadaan buku teks pelajaran kurikulum 2013 menggunakan dana BOS harus melalui Lembaga Kebijakan Pengadaan Barang/ Jasa Pemerintah (LKPP), karena dalam
Peraturan Presiden Nomor 54 Tahun 2010 tentang Pengadaan Barang/Jasa Pemerintah, dijelaskan bahwa pengadaan barang/jasa yang dibeli dari anggaran Pemerintah seperti anggaran pendapatan dan belanja nasional (APBN) atau anggaran pendapatan dan belanja daerah (APBD) harus melalui LKPP. Untuk pengadaan buku teks pelajaran kurikulum 2013 melalui e-katalog Kementerian Pendidikan dan Kebudayaan (Kemdikbud) bekerjasama dengan LKPP. Peraturan Presiden Nomor 54 Tahun 2010 diperbaharui menjadi Peraturan Presiden Republik Indonesia Nomor 4 Tahun 2015.

Pada tahun 2016/2017, Pemerintah menyediaan buku teks melalui e-katalog atau e-purchasing. Pengadaan buku melalui e-katalog, yaitu pembelian dilakukan sekolah melalui online ke alamat e-katalog.lkpp.go.id. Penyedia yang terdapat dalam e-katalog sudah ditetapkan sebanyak 10 penyedia.

Tahun 2017/2018, Pemerintah kembali menyediakan buku teks pelajaran melalui BSE yang sudah lebih baik dari BSE 2008 . Siapapunitubaikindividu, sekolah, kelompok/ lembaga maupun penyedia dapat mengunduh, mengkopi, mencetak dan menggandakan buku teks pelajaran kurikulum 2013 melalui laman buku.kemdikbud.go.id sesuai dengan kebutuhan. Penyediaan buku teks pelajaran melalui BSE tidak harus pemerintah yang menyediakan, tetapi boleh perorangan, sekolah, percetakan kecil maupun percetakan besar. Sekolah juga dapat membeli langsung melalui sales marketing dari penyedia buku teks pelajaran yang datang ke sekolah untuk menawarkan buku dengan harga yang sudah ditetapkan oleh pemerintah.

Sekolah-sekolah di Kabupaten Natuna merupakan salah satu konsumen pengadaan 
buku teks pelajaran kurikulum 2013. Untuk mengetahui pengadaan buku teks kurikulum 2013, maka perlu ada kajian atau penelitian Pelaksanaan Pengadaan Buku Teks Pelajaran Kurikulum 2013 di Kabupaten Natuna.

Tujuan penelitian ini adalah untuk menganalisis mekanisme pelaksanaan pengadaan buku teks pelajaran kurikulum 2013 dan kendalanya serta sumber pendanaan pengadaan buku teks di Kabupaten Natuna.

\section{KAJIAN LITERATUR}

Menurut Irawan, Zaenal, Eka Sari, Maya, Umi Setyoningrum, Muthia (2011), BSE adalah inisiatif dari Kementerian Pendidikan Nasional dan Kebudayaan yang bertujuan menyediakan buku ajar elektronik (e-book) yang bermutu, murah, dan terjangkau untuk tingkat pendidikan SD, SMP, SMA, dan SMK. Buku-buku teks pelajaran yang masuk dalam BSE dibeli hak ciptanya dari penulis/penerbit dan diubah dalam bentuk buku elektronik (ebook). Buku teks pelajaran yang ada dalam BSE dinyatakan telah memenuhi SNP oleh badan standar nasional pendidikan (BSNP). BSE ditujukan bagi siswa, guru, dan seluruh masyarakat untuk: (i) menyediakan sumber belajar alternatif bagi siswa; (ii) merangsang siswa untuk berpikir kreatif dengan bantuan teknologi informasi dan komunikasi (TIK); (iii) memberi peluang untuk menggandakan, mencetak,memfotokopi,mengalih-mediakan, dan/atau memperdagangkan BSE tanpa prosedur perijinan, dan bebas biaya royalty sesuai dengan ketentuan yang diberlakukan Menteri; (iv) memberikan peluang bisnis bagi siapa saja untuk menggandakan dan memperdagangkan dengan proyeksi keuntungan $15 \%$ sesuai dengan ketentuan yang diberlakukan Menteri.
Untuk mendapatkan buku teks pelajaran kurikulum 2013 sekolah melakukan berbagai cara, seperti membeli langsung ke toko buku, membeli secara online melalui onlineshop (e-katalog), atau membeli melalui sales marketing dari penerbit buku yang datang ke sekolah. Pengadaan buku teks tersebut ada mekanismenya.

Menurut AS, Moenir (2001), mekanisme adalah suatu rangkaian kerja sebuah alat yang digunakan dalam menyelesaikan sebuah masalah yang berkaitan dengan proses kerja. Tujuannya adalah untuk menghasilkan hasil yang maksimal serta mengurangi kegagalan. Sementara menurut Bagus, Lorens (1996), mekanisme adalah interaksi bagian satu dengan bagian lainnya dalam suatu sistem secara keseluruhan untuk menghasilkan fungsi atau kegiatan sesuai tujuan. Berdasarkan definisi di atas dapat disimpulkan, mekanisme ialah suatu rangkaian kerja yang saling interaksi bagian satu dengan lainnya secara keseluruhan untuk menyelesaikan sebuah masalah yang berkaitan dengan proses kerja dan menghasilkan hasil yang maksimal sesuai tujuan.

Pengadaan buku teks pelajaran merupakan kegiatan untuk memperoleh buku teks pelajaran yang dilakukan oleh sekolah. Mekanisme pengadaan buku teks pelajaran kurikulum 2013, adalah cara yang dilakukan sekolah untuk memperoleh buku teks pelajaran kurikulum 2013 agar proses pembelajaran dapat berlangsung dengan baik sesuai dengan tujuan pembelajaran. Mekanisme pembelian/pengadaan buku teks pelajaran kurikulum 2013 di tahun 2017, yaitu: a) sekolah memesan buku teks ke penyedia buku baik secara langsung (offline) maupun online pada laman buku,kemdikbud. 
go.id yang disediakan olek Kementerian Pendidikan dan Kebudayaan; b) penyedia buku mengirimkan buku teks kepada sekolah sesuai dengan pesanan; c) sekolah melakukan pemeriksaan kesesuaian terhadap:(i)juduldan isi buku; (ii) spesifikasi buku teks pelajaran kurikulum 2013 yang telah ditetapkan oleh Kementerian Pendidikan dan Kebudayaan; dan (iii) jumlah pesanan buku setiap judul; d) sekolah melakukan pembayaran pemesanan buku teks pelajaran kurikulum 2013 kepada penyedia buku sesuai dengan harga yang tidak melebihi harga eceran tertinggi (HET). (http://dikdasmen.kemdikbud.go.id/bse/)

Untuk pembelian buku teks pelajaran dengan dana BOS dijelaskan dalam Peraturan Menteri Pendidikan dan Kebudayaan Nomor 1 Tahun 2018 tentang Petunjuk Teknis BOS, bahwa Sekolah wajib menggunakan sebagian dana BOS untuk membeli buku teks utama untuk pelajaran dan panduan guru sesuai dengan kurikulum yang digunakan oleh sekolah dengan ketentuan sebagai berikut:

a. Buku teks utama harus sudah dibeli oleh atau tersedia di sekolah sebelum Tahun Pelajaran Baru dimulai. Sekolah dapat menggunakan BOS triwulan I dan triwulan II (bagi sekolah yang menerima penyaluran tiap triwulan) atau semester I (bagi sekolah yang menerima penyaluran tiap semester) untuk membiayai pembelian buku teks utama.

b. Sekolah harus mencadangkan separuh BOS yang diterima di triwulan II (untuk sekolah yang menerima BOS tiap triwulan) atau sepertiga dari BOS yang diterima di semester I (untuk sekolah yang menerima BOS tiap semester), atau 20\% dari alokasi sekolah dalam satu tahun di rekening sekolah untuk pembayaran buku teks utama yang harus dibeli sekolah. Dana yang dicadangkan ini hanya boleh dicairkan apabila sekolah hendak membayar pesanan buku teks utama yang diperlukan atau sudah memenuhi kewajiban penyediaan buku teks utama.

c. Dana $20 \%$ yang dicadangkan tersebut tidak berarti bahwa sekolah harus membeli buku teks utama dengan seluruh dana tersebut. Pembelian buku teks utama dilaksanakan sesuai dengan kebutuhan setiap sekolah dengan kewajiban penyediaan buku sesuai ketentuan sebagai berikut:

1) Apabila penggunaan dana untuk pembelian buku teks utama lebih besar dari $20 \%$ dana BOS yang telah dicadangkan, sekolah dapat menambahkan dana tersebut dari dana yang ada.

2) Apabila penggunaan dana untuk pembelian buku teks utama lebih sedikit dari $20 \%$ dana BOS yang telah dicadangkan, maka sisa dana tersebut dapat digunakan untuk pembelian buku lainnya atau pembiayaan kegiatan/komponen belanja lainnya.

Pengadaan buku teks pelajaran melalui e-katalog atau BSE belum dapat dimanfaatkan secara optimal oleh sekolah yang disebabkan berbagai faktor. Menurut hasil penelitian Andina, Elga, (2011), penyebab kurang efektifnya BSE di Jawa Timur disebabkan oleh faktor-faktor berikut: (i) tidak semua daerah memiliki sarana komputer dan internet yang memadai; (ii) siswa lebih cenderung menyukai cetakan konvensional, sehingga mencetak hasil unduhan; (iii) terjadi penyimpangan oleh penerbit; dan BSE dianggap tidak cukup komprehensif untuk 
membantu pembelajaran siswa, karena masih terbatas tulisan belum dilengkapi dengan tampilan multimedia untuk mendukung proses pembelajaran.

Selanjutnya, hasil penelitian Irawan, Zaenal, Eka Sari, Maya, Umi Setyoningrum, Muthia (2011), menunjukkan bahwa "kebijakan BSE secara teknis dipandang sudah siap, tetapi ternyata masih ada kekurangan diantaranya belum semua buku teks pelajaran pokok tersedia di BSE, belum ada server khusus di masing-masing wilayah untuk mempermudah dalam mengakses BSE, dan belum ada sistem pengawasan dan koordinasi yang jelas antara Kemdikbud dan Dinas Pendidikan (Disdik) Kabupaten/Kota".

Hasil penelitian Surya Hasnita, Siska, Sundarso, Slamet Santoso, R, (2014) menunjukan bahwa "SMA 9 Kota Semarang telah memiliki kesiapan akan pemahaman dan sarana prasarana yang baik untuk pelaksanaan program BSE. Namun pelaksanaan program BSE ini belum maksimal dan apa yang menjadi tujuan pun belum tercapai. Terdapat beberapa faktor yang mempengaruhi pelaksanaan BSE, antara lain: (1) Sosialisasi; (2) Petunjuk teknis; (2) Koordinasi yang kurang antara pemerintah dan sekolah; dan (3) Proses pendistribusian yang tidak dilakukan. Dari hal tersebut, dituntut kesiapan dari pemerintah akan pelaksanaan kebijakan, kejelasan akan sosialisasi dan petunjuk teknis serta koordinasi yang baik antara stakeholder dalam pencapaian tujuan yang di tetapkan”.

Menurut Undang-Undang Nomor 3 Tahun 2017 tentang Sistem Perbukuan, dijelaskan bahwa "Buku adalah karya tulis dan/atau karya gambar yang diterbitkan berupa cetakan berjilid atau publikasi elektronik yang diterbitkan secara tidak berkala. Bentuk buku terbagi dua, yaitu buku cetak dan buku elektronik. Buku cetak, yakni karya tulis berupa teks, gambar, atau gabungan keduanya yang dipublikasikan dalam bentuk cetak. Buku elektronik ialah karya tulis berupa teks, gambar, audio, video, atau gabungan dari keseluruhan yang dipublikasikan dalam bentuk elektronik. Jenis buku terbagi menjadi buku pendidikan dan buku umum. Buku pendidikan ialah buku yang digunakan dalam pendidikan umum, kejuruan, akademik, profesi, vokasi, keagamaan, dan pendidikan khusus. Buku pendidikan dibagi menjadi dua, yaitu buku teks dan buku non teks. Buku teks terdiri dari buku teks utama dan buku pendamping. Buku teks utama adalah buku pelajaran yang wajib dipakai dalam pembelajaran berdasarkan kurikulum yang berlaku dan di sediakan oleh Pemerintah Pusat tanpa dipungut biaya. Buku teks pendamping adalah buku pelajaran yang disusun oleh masyarakat berdasarkan kurikulum yang berlaku dan telah mendapatkan pengesahan dari pemerintah pusat. Buku umum adalah jenis buku di luar buku pendidikan”.

Dalam Permendikbud No.8 Tahun 2016 Tentang Buku yang digunakan oleh satuan pendidikan, Pasal 6, menyebutkan bahwa

"Penilaian atas kriteria kelayakan buku teks pelajaran maupun buku non teks pelajaran diajukan oleh penerbit kepada Kementerian atau BSNP. Kriteria atas kelayakan buku teks pelajaran yang diterbitkan oleh Kementerian dilakukan oleh Tim Penelaah yang ditetapkan oleh Menteri Pendidikan dan Kebudayaan. Kriteria atas kelayakan buku teks pelajaran yang diterbitkan oleh swasta dapat dilakukan penilaian oleh BSNP atau Tim penilai yang ditetapkan oleh Menteri Pendidikan dan Kebudayaan. Kriteria atas kelayakan buku 
non teks pelajaran sebagai buku yang layak digunakan oleh satuan pendidikan ditetapkan oleh Kementerian melalui proses penilaian". Pasal 9, menjelaskan bahwa "Satuan pendidikan wajib memilih dan menyediakan buku teks pelajaran yang dinyatakan layak oleh Kementerian untuk digunakan dalam proses pembelajaran. Satuan pendidikan wajib melakukan evaluasi seluruh buku yang digunakan di satuan pendidikan untuk memastikan buku yang digunakan di satuan pendidikan wajib memenuhi nilai/norma positif yang berlaku di masyarakat, antara lain tidak mengandung unsur pornografi, paham ekstrimisme, radikalisme, kekerasan, SARA, bias gender, dan tidak mengandung nilai penyimpangan lainnya."

Selain itu, Pasal 3, kriteria buku teks pelajaran wajib memenuhi unsur: (i) kulit buku meliputi kulit depan buku, kulit belakang buku, dan punggung buku; (ii) bagian awal buku wajib memenuhi halaman judul, halaman penerbitan, halaman kata pengantar, halaman daftar isi, halaman daftar gambar, halaman tabel, dan penomoran halaman; (iii) bagian isi buku wajib memenuhi aspek materi, aspek kebahasaan, aspek penyajian materi, dan aspek kegrafikaan; bagian akhir buku teks pelajaran wajib memenuhi informasi tentang pelaku perbukuan, glosarium, daftar pustaka, indeks, dan lampiran; (iv) bagian akhir buku.

Bagian isi buku teks pelajaran yang terdiri dari aspek materi, kebahasaan, penyajian, dan aspek kegrafikaan perlu memperhatikan hal-hal berikut.

a. Aspek Materi meliputi: (i) harus dapat menjaga kebenaran dan keakuratan materi, kemuktahiran data dan konsep, serta dapat mendukung pencapaian tujuan pendidikan nasional; (ii) menggunakan sumber materi yang benar secara teoritik dan empirik; (iii) mendorong timbulnya kemandirian dan inovasi; (iv) mampu memotivasi untuk mengembangkan dirinya; dan (v) mampu menjaga persatuan dan kesatuan bangsa dengan mengakomodasi kebhinekaan, sifat gotong royong, dan menghargai perbagai perbedaan.

b. Aspek Kebahasaan mencakup: penggunaan bahasa (ejaan, kata, kalimat, dan paragraf) tepat, lugas, jelas, serta sesuai dengan tingkat perkembangan usia; (ii) ilustrasi materi, baik teks maupun gambar sesuai dengan tingkat perkembangan usia pembaca dan mampu memperjelas materi/ konten; (iii) bahasa yang digunakan komunikatif dan informatif, sehingga pembaca mampu memahami pesan positif yang disampaikan, memiliki ciri edukatif, santun, etis, dan estetis sesuai dengan tingkat perkembangan usia; dan (iv) judul buku dan judul bagian-bagian materi/ konten buku harmonis/selaras, menarik, mampu menarik minat untuk membaca dan tidak provokatif.

c. Aspek penyajian materi, yaitu: (i) materi buku disajikan secara menarik (runtut, koheren, lugas, mudah dipahami, dan interaktif), sehingga keutuhan makna yang ingin disampaikan dapat terjaga dengan baik; (ii) ilustrasi materi, baik teks maupun gambar menarik sesuai dengan tingkat perkembangan usia pembaca dan mampu memperjelas materi/konten serta santun; (iii) penggunaan ilustrasi untuk memperjelas materi tidak mengandung unsur pornografi, paham ekstrimisme, radikalisme, kekerasan, SARA, bias gender, dan tidak mengandung nilai 
penyimpangan lainnya; (iv) penyajian materi dapat merangsang untuk berpikir kritis, kreatif, dan inovatif; (v) mengandung wawasan kontekstual, dalam arti relevan dengan kehidupan keseharian serta mampu mendorong pembaca untuk mengalami dan menemukan sendiri hal positif yang dapat diterapkan dalam kehidupan seharian; (vi) penyajian materi menarik sehingga menyenangkan bagi pembacanya dan dapat menumbuhkan rasa keingintahuan yang mendalam.

d. Aspek Kegrafikaan terdiri dari: (i) ukuran buku sesuai dengan tingkat perkembangan usia dan materi/konten buku; (ii) tampilan tata letak unsur kulit buku sesuai/ harmonis dan memiliki kesatuan (unity); (iii) pemberian warna pada unsur tata letak harmonis dan dapat memperjelas fungsi; (iv) penggunaan huruf dan ukuran huruf disesuaikan dengan tingkat perkembangan usia; dan ilustrasi yang digunakan mampu memperjelas pesan yang ingin disampaikan.

Buku teks yang baik, yaitu buku teks yang berkualitas dan bermutu. Menurut Tarigan, Djago, H. G. Tarigan (1986:22), untuk menentukan kualitas buku teks ada 11 aspek yang harus dipenuhi, yaitu: (i) memiliki landasan prinsip dan sudut pandang berdasarkan teori linguistik, ilmu jiwa perkembangan, dan teori bahan pembelajaran; (ii) kejelasan konsep, (iii) relevan dengan kurikulum yang berlaku, (iv) sesuai dengan minat siswa, (v) menumbuhkan motivasi belajar, (vi) merangsang, menantang, dan menggairahkan aktivitas siswa, (vii) ilustrasi tepat dan menarik, (viii) mudah dipahami siswa, yaitu bahasa yang digunakan memiliki karakter yang sesuai dengan tingkat perkembangan bahasa siswa, kalimatkalimatnya efektif, terhindar dari makna ganda, sederhana, sopan, dan menarik, (ix) dapat menunjang mata pelajaran lain, (x) menghargai perbedaan individu, kemampuan, bakat, minat, ekonomi, sosial dan budaya, (xi) memantapkan nilai-nilai budi pekerti yang berlaku di masyarakat. Hasil penelitian dari Ayuningtyas, Riza dan Budiyono (2016), membuktikan bahwa buku pelajaran Bahasa Indonesia untuk SMP dari semua kriteria penilaian masuk kategori sudah baik dan layak untuk digunakan.

Buku teks pelajaran juga memiliki kelemahan. Menurut Efendi, Anwar (2009), kelemahan buku teks pelajaran dikelompokkan menjadi tiga aspek, yaitu: (i) aspek materi; (ii) aspek penyajian, dan (iii) aspek kebahasaan. Sebagai contoh kelemahan buku teks pelajaran Bahasa dan Sastra Indonesia dari aspek materi adalah sebagai berikut: (i) materi belum proposional, masih ditemukan buku yang kekurangan materi; (ii) masih ditemukan materi yang belum disajikan, khususnya materi kebahasaan; (iii) kebahasaan dan kesastraan bersifat teoritis sehingga belum mengarah pada proses pembelajaran; (iv) teori yang disajikan masih mengandung kesalahan; (v) pengalaman berbahasa dan bersastra sering diabaikan; (vi) masih ditemukan juga materi lengkap, tetapi hanya berupa informasi dan definisi yang sifatnya ensiklopedia, tidak diolah atau diterapkan; (vii) keterpaduan materi sangat lemah, seperti antar kompetensi maupun tema; (viii) ragam wacana, khususnya wacana radio, TV, kutbah, pidato masih belum tepat. Aspek penyajian materi, yaitu (i) praktik mandiri atau kerja kelompok belum dikembangkan dengan efektif; (ii) sajian masih berupa 
perintah-perintah yang monoton; (iii) masih ditemukan tatanan pikiran yang tidak sistematis; (iv) langkah-langkah mengenali permasalahan dan cara mengatasinya belum dikembangkan dengan efektif; (v) perintah kerja belum jelas, belum operasional, dan belum diikuti dengan contoh yang memadai; (vi) tujuan tidak dirumuskan dengan baik; (vii) pada beberapa buku, soal hanya disajikan pada akhir buku; (viii) pertanyaan tidak sesuai dengan bacaan; (ix) penyajian materi, khususnya SMA program studi bahasa antara materi dan berbahasa dengan bersastra dibuat menjadi dua lapis; (x) tidak melibatkan siswa untuk mendapatkan pengalaman berbahasa dan bersastra, melainkan menyediakan istilah teknis; (xi) penyajian disusun dengan cara yang tidak memungkinkan siswa untuk menyimpulkan sendiri; (xii) pengolahan bahan belum dilakukan dengan baik, sehingga tidak menarik minat; (xiii) pembelajaran masih berpusat pada guru. Kelemahan dari aspek bahasa dan keterbacaan sebagai berikut: (i) penggunaan bahasa dan tata tulis masih mengandung banyak kesalahan; (ii) keterbacaan bahan bacaan masih rendah, ditandai dengan kata-kata yang terlalu sulit dan kalimat panjang-panjang; (iii) tingkat kesulitan antara jenjang yang lebih rendah dengan yang tinggi berbeda; (iv) istilah tidak diuraikan dan siswa harus langsung bekerja; (v) jenis wacana sering diubah; (vi) pilihan wacana terlalu berat dan isinya mengerikan karena menceritakan hal-hal negatif; (vii) penggunaan sumber kutipan yang tidak sesuai dengan siswa; (viii) sumber kutipan lebih bertumpu pada satu sumber; (ix) banyak gambar yang tidak sesuai dengan isi wacana; (x) buku tidak menyediakan soal untuk mengevaluasi kemampuan dan pemahaman siswa; (xi) kutipan-kutipan bersifat historis sering salah; (xii) sumber kutipan tidak disertakan; (xiii) sumber kutipan terbatas. Kelemahan buku teks tersebut, diperkuat dari hasil penelitian Hendrawanto, Yusuf (2017) menunjukkan bahwa buku teks pelajaran SMA/SMK yang dinilai menggunakan Standar BSNP, dilihat dari aspek kelayakan kebahasaan, isi, penyajian, dan kegrafikaan ternyata masih tergolong kurang layak. Hasil tersebut diperoleh dari hasil penilaian dan analisis peneliti dari buku teks kelas X, XI, dan XII semester 1 dan 2 terbitan Kemdikbud (2014, 2014, 2015, 2015, dan 2016). Artinya buku teks SMA/SMK tersebut perlu ada revisi atau perubahan.

Hasil penelitian lainnya tentang buku teks pelajaran, yaitu penelitian Novianto, Anwar, dan Mustadi, Ali (2015), menunjukan bahwa: (i) sebagian besar indikator keterpaduan pada buku teks sesuai, tetapi masih ada kesalahan dalam penomoran KD dan ketidaksesuaian dengan materi dengan KD; (ii) muatan scientific approach yang tercantum pada buku teks mencakup kegiatan bervariasi yang mengarahkan siswa untuk berinteraksi dengan lingkungan dalam membangun pengetahuan; (iii) muatan authenthic assessment sudah memenuhi sebagian besar indikator, tetapi masih perlu dilengkapi dengan rubrik penilaian untuk membantu guru dalam menerapkan penilaian sikap, pengetahuan, dan keterampilan.

Sementara menurut Nasution dalam Prastowo, Andi (2012:169) menyebutkan bahwa buku teks pelajaran memiliki beberapa fungsi dan tujuan, yaitu: 1). Sebagai bahan referensi atau bahan rujukan oleh peserta didik; 2). Sebagai bahan evaluasi; 3). Sebagai alat bantu pendidik dalam melaksanakan 
kurikulum; 4). Sebagai salah satu penentu metode atau teknik pengajaran yang akan digunakan pendidik; dan 5). Sebagai sarana untuk peningkatan karir dan jabatan. Tujuan pengadaan buku teks pelajaran, yaitu: 1). untuk memudahkan pendidik dalam menyampaikan materi pembelajaran; 2). Memberikan kesempatan kepada peserta didik untuk mengulang pelajaran atau mempelajari pelajaran baru; dan 3). Menyediakan materi pembelajaran yang menarik bagi peserta didik.

Hasil penelitian Rahmawati, Gustini (2015), menunjukkan bahwa, penilaian siswa tentang kualitas, materi, dan penyajian materi buku teks pelajaran berada pada kategori baik. Sementara untuk aspek kebahasaan buku teks pelajaran berada pada kategori cukup baik.

Hasil penelitian lainnya, yaitu dari Yusmium, Ika (2015), menunjukkan bahwa buku Ilmu Pengetahuan Alam (IPA) terbitan Kemdikbud sudah memenuhi kriteria sangat baik (96\%) dan memenuhi standar buku teks. Hasil penelitian Ilham, Muhammad (2009), menunjukan bahwa "peran buku sekolah elektronik dalam proses pelaksanaannya dapat berjalan efektif dan efisien atau tergolong baik, karena hasil perhitungan persentase menunjukkan $48,88 \%$. Sementara peningkatan prestasi siswa di SDN Jetak Probolinggo setelah diterapkan BSE mengalami peningkatan dalam pencapaian hasil belajar siswa pada bidang studi Pendidikan Agama Islam (PAI) yang cukup, hal ini berdasarkan pada hasil perhitungan prosentase $55,64 \%$ dengan kriteria tergolong baik. Peranan BSE di SDN Jetak Probolinggo mempunyai dampak yang positif terhadap peningkatan prestasi belajar siswa pada bidang PAI dalam katagori sedang atau kecukupan. Hal ini, berdasarkan hasil perhitungan product moment 0,45 dan pada tabel interpretasi berada pada nilai $\mathrm{r}=0,40$ - 0,70 yang menunjukkan bahwa antara variable x dan y terdapat pengaruh sedang".

\section{METODE PENELITIAN}

Penelitian ini menggunakan pendekatan kualitatif dengan melakukan penelusuran pelaksanaan pengadaan buku teks pelajaran kurikulum 2013, kendala yang dihadapi dan sumber dana yang digunakan untuk membeli buku teks kurikulum 2013. Populasi studi ini yaitu jenjang satuan pendidikan dasar dan menengah di Kabupaten Natuna. Teknik pemilihan sampel menggunakan purposive sampling.

Data yang digunakan adalah data tahun pelajaran (TP) 2016/2017 dan 2017/2018. Narasumber terdiri atas unsur Disdik Kabupaten Natuna, Satuan Pendidikan sekolah dasar (SD), sekolah menengah pertama (SMP), dan sekolah menengah atas (SMA). Teknik pengumpulan data dan informasi dilakukan dengan diskusi kelompok terpumpun (DKT) yang menggunakan panduan DKT. DKT bertujuan untuk menganalisis mekanisme pola pelaksanaan pengadaan buku teks pelajaran kurikulum 2013 dan kendalanya serta sumber pendanaan pengadaan buku teks di Kabupaten Natuna.

Pengolahan dan analisis data menggunakan analisis deskriptif kualitatif. Analisis data deskriptif kualitatif dengan melakukan reduksi, mengklasifikasikan, menyajikan dan menyimpulkan.

\section{HASIL DAN PEMBAHASAN}

Mekanisme Pengadaan Buku Teks Pelajaran Kurikulum 2013 di Kabupaten 


\section{Natuna.}

Menurut data Badan Pusat Statistik (BPS) Kabupaten Natuna (2018), data angka partisipasi murni (APM) tahun 2017 untuk $\mathrm{SD}=98,62, \mathrm{SMP} / \mathrm{MTs}=89,80$, dan SMA/ $\mathrm{SMK} / \mathrm{MA}=69,56$. Sementara APK SD $=$ 106,62, SMP/MTs $=95,48, \mathrm{SMA} / \mathrm{SMK} / \mathrm{MA}$ $=84,50$. Jumlah sekolah yang terdapat di Kabupaten Natuna tahun 2017/2018, yaitu: SD sebanyak 80 sekolah, SMP 21 sekolah, SMA 15 sekolah, dan SMK sebanyak 7 sekolah. (http://dapo.dikdasmen.kemdikbud. go.id/sp/1/310000)

Dalam pendidikan terdapat komponen pendidikan yang merupakan unsur-sunsur penentu ada tidaknya serta tercapai atau tidaknya proses pendidikan. Menurut Ahmad Tafsir (2008 dalam Rahmanto, Sujari, 2019:3), komponen pendidikan terdiri dari: 1) tujuan; 2) pendidik; 3) peserta didik; 4) kepala sekolah sampel, penentuan buku teks yang akan dibeli dilakukan dengan mufakat melalui rapat dengan para guru yang ada di sekolah masing-masing untuk menentukan buku teks pelajaran mana yang akan dipakai di sekolah, karena banyak buku teks pelajaran yang diterbitkan oleh banyak penyedia/ penerbit.

Pengadaan buku teks pelajaran kurikulum 2013 pada tahun 2016/2017 di Kabupaten Natuna dilaksanakan melalui e-katalog dan pada tahun 2017/2018 melalui buku sekolah elektronik (BSE). Namun ada kebijakan pada TP 2017/2018 pengadaan buku teks pelajaran kurikulum 2013 dilakukan dengan dua cara, yaitu semester 1 melalui e-katalog dan semester 2 melalui buku sekolah elektronik. Berikut sampel sekolah yang melakukan pengadaan buku teks pelajaran kurikulum 2013 pada tahun 2016/2017 dan 2017/2018.

Tabel 1.1. Pengadaan buku teks pelajaran oleh sekolah melalui e-katalog

(TP 2106/2017)

\begin{tabular}{|c|c|c|c|}
\hline No & Komponen & SMPN 1 Bunguran Timur & SMAN 1 Bunguran Timur \\
\hline 1. & $\begin{array}{l}\text { Mekanisme } \\
\text { pengadaan }\end{array}$ & $\begin{array}{l}\text { - Melalui internet } \\
\text { - Penyedia Tiga Serangkai }\end{array}$ & $\begin{array}{l}\text { - } \text { Melalui internet } \\
\text { - Penyedia Gramedia } \\
\text { - Untuk buku peminatan pesan } \\
\text { melalui offline ke Printing }\end{array}$ \\
\hline
\end{tabular}

2. Lama Pengiriman 4 bulan 4 Bulan

kurikulum; 5) metode; 6) buku teks siswa dan guru; 7) pembiayaan; 8) ruang kelas; 9) perangkat keras; dan 10) kegiatan.

Untuk memenuhi salah satu komponen pendidikan, yaitu pengadaan buku teks siswa dan guru, maka sekolah-sekolah di Kabupaten Natuna melakukan transaksi pengadaan buku melalui e-katalog maupun BSE. Menurut
Tabel 1, menunjukkan bahwa kedua sekolah sampel melakukan pengadaan buku teks dengan cara membeli melalui e-katalog kepada penyedia/penerbit buku teks yang besar, sehingga walaupun terlambat datang ke sekolah pengiriman buku masih dapat dilakukan. Untuk buku peminatan di SMAN 1 Bungur Timur, pihak sekolah 
memilih membeli melalui usaha printing empat (4) bulan. Penyebab keterlambatan Verri Colection walaupun kedua penyedia tidak diketahui oleh sekolah. mengirimkan bukunya terlambat sampai

Tabel 1.2. Pengadaan buku teks pelajaran oleh sekolah melalui BSE

\begin{tabular}{|c|c|c|c|c|c|c|}
\hline No & Komponen & $\begin{array}{c}\text { SDN } 009 \text { Bandar- } \\
\text { syah }\end{array}$ & SDN 012 Ranai & $\begin{array}{l}\text { SDN } 002 \\
\text { Ranai }\end{array}$ & $\begin{array}{c}\text { SDN } 005 \\
\text { Sepem-pang }\end{array}$ & $\begin{array}{c}\text { SMPN 1 } \\
\text { Bunguran } \\
\text { Timur }\end{array}$ \\
\hline 1 & $\begin{array}{l}\text { Mekanisme } \\
\text { pengadaan }\end{array}$ & $\begin{array}{l}\text { - Pembelian } \\
\text { buku langsung } \\
\text { ke toko buku } \\
\text { - Pembelian } \\
\text { buku dilakukan } \\
\text { seca ra berta- } \\
\text { hap yaitu: } \\
\text { semester 1 } \\
\text { membeli buku } \\
\text { utk Kelas I } \\
\text { sesuai dgn } \\
\text { jumlah siswa } \\
\text { permata pela- } \\
\text { jaran. Semester } \\
2 \text { membeli } \\
\text { buku utk Kls II } \\
\text { sesuai jumlah } \\
\text { siswa per mata } \\
\text { pelajaran } \\
\end{array}$ & $\begin{array}{l}\text { - Mencopy } \\
\text { buku BSE } \\
\text { sesuai } \\
\text { jumlah siswa } \\
\text { Kelas I dan } \\
\text { IV }\end{array}$ & $\begin{array}{l}\text { Dibagi dlm } 2 \\
\text { tahap. } \\
\text { - Semester } 1 \\
\text { pembelian } \\
\text { secara } \\
\text { online ke } \\
\text { Gramedia. } \\
\text { - Semester } 2 \\
\text { pembelian } \\
\text { secara } \\
\text { offline } \\
\text { melalui toko } \\
\text { buku. }\end{array}$ & $\begin{array}{l}\text { Dibagi dlm } 2 \\
\text { tahap. } \\
\text { - Semester } 1 \\
\text { pembelian } \\
\text { secara } \\
\text { online ke } \\
\text { Gramedia. } \\
\text { - Semester } 2 \\
\text { pembelian } \\
\text { secara } \\
\text { offline } \\
\text { melalui toko } \\
\text { buku }\end{array}$ & $\begin{array}{l}\text { - Sekolah } \\
\text { langsung } \\
\text { men- } \\
\text { datangi } \\
\text { toko buku } \\
\text { (offline) }\end{array}$ \\
\hline 2 & $\begin{array}{l}\text { Lama } \\
\text { Pengiriman }\end{array}$ & $\begin{array}{l}\text { Tiga bulan } \\
\text { (pesan awal } \\
\text { Juni, buku } \\
\text { dite-rima seko } \\
\text {-lah akhir } \\
\text { Agustus) } \\
\end{array}$ & - 1Minggu & $\begin{array}{l}\text { - } 3 \text { Bulan } \\
\text { baik online } \\
\text { maupun } \\
\text { offline }\end{array}$ & $\begin{array}{l}\text { - } 3 \text { Bulan } \\
\text { baik onli- } \\
\text { ne maupun } \\
\text { offline }\end{array}$ & - 4 Bulan \\
\hline No & Komponen & $\begin{array}{c}\text { SMPN 1 } \\
\text { Bunguran Timur } \\
\text { Laut }\end{array}$ & $\begin{array}{l}\text { SMPS Nurul } \\
\text { Jannah }\end{array}$ & $\begin{array}{c}\text { SMPN 1 } \\
\text { Bunguran } \\
\text { Batubi }\end{array}$ & $\begin{array}{c}\text { SMAN 1 } \\
\text { Bunguran } \\
\text { Timur }\end{array}$ & $\begin{array}{c}\text { SMAN } 2 \\
\text { Bunguran } \\
\text { Timur }\end{array}$ \\
\hline 1 & $\begin{array}{l}\text { Mekanisme } \\
\text { pengadaan }\end{array}$ & $\begin{array}{l}\text { - Pembelian } \\
\text { buku secara } \\
\text { offline (Sekolah } \\
\text { langsung } \\
\text { mendatangi } \\
\text { toko buku) }\end{array}$ & $\begin{array}{l}\text { - Sekolah } \\
\text { langsung } \\
\text { mendatangi } \\
\text { toko buku } \\
\text { (offline) }\end{array}$ & $\begin{array}{l}\text { - Sekolah } \\
\text { langsung } \\
\text { mendatangi } \\
\text { toko buku } \\
\text { (offline) }\end{array}$ & $\begin{array}{l}\text { - Pembelian } \\
\text { buku secara } \\
\text { online dan } \\
\text { offline } \\
\text { (Sekolah } \\
\text { langsung } \\
\text { mendatangi } \\
\text { perusahaan } \\
\text { Printing } \\
\text { sebagai } \\
\text { distributor } \\
\text { buku yang } \\
\text { ada di } \\
\text { Natuna) } \\
\end{array}$ & $\begin{array}{l}\text { - Pembelian } \\
\text { buku } \\
\text { secara ke } \\
\text { perusahaan } \\
\text { printing } \\
\text { offline }\end{array}$ \\
\hline 2 & $\begin{array}{l}\text { Lama } \\
\text { Pengiriman }\end{array}$ & - 4 Bulan & - 4 Bulan & - 5 Bulan & - 3 Bulan & - 6 Bulan \\
\hline
\end{tabular}


Tabel 2, menunjukkan sekolah-sekolah sampel melakukan pengadaan buku teks ada yang melalui online dan offline. Namun keduanya sama-sama tidak tepat waktu dalam pengirimannya dan pembeliannya ada yang bertahap serta ada yang langsung disesuaikan dengan kebutuhan dan kondisi keuangan sekolah masing-masing.

Sekolah-sekolah di Kabupaten Natuna untuk pembelian buku teks pelajaran kurikulum 2013 menggunakan 20\% dana bantuan operasional sekolah (BOS) sesuai dengan petunjuk teknis (Juknis) BOS yang telah ditetapkan oleh pusat. Hal tersebut diperkuat dari hasil penelitian Sumarni, Neni (2015) dalam analisis terhadap penggunaan dana BOS, SMP Satap 6 Rambah Samo menggunakan dana BOS antara lain untuk pengembangan perpustakaan meliputi: a) wajib membeli buku teks pelajaran kurikulum 2013 bagi peserta didik dan guru; b) membeli kekurangan buku teks pelajaran kurikulum 2013 atau mengganti buku yang rusak di kelas lainnya; c) membeli buku teks pelajaran 2013 untuk peserta didik sebagai cadangan yang disimpan di perpustakaan sebanyak $5 \%$ dari jumlah peserta. Program pelaksanaan dana BOS SMPN 6 SATAP Rambah Samo termasuk dalam kategori sedang dikarenakan masih ada yang belum sesuai pelaksanaannya dengan peraturan yang berlaku.

Mekanisme pengadaan buku teks pelajaran kurikulum 2013 melalui e-katalog langkah pertama yang harus dilakukan oleh sekolah, yaitu sekolah masuk laman lkpp. go.id. Selanjutnya, sekolah memilih buku teks pelajaran Kurikulum 2013 yang akan dipesan. Kemudian, sekolah melakukan pemesanan dengan mengisi formulir yang berisi judul atau tema buku teks untuk kelas berapa, jumlahnya berapa, karena aplikasi LKPP sudah terkoneksi dengan Dapodik, maka alamat sekolah pemesan berdasarkan alamat yang terdapat dalam Dapodik. Pembayaran buku teks melalui e-katalog umumnya dibayarkan setelah buku teks diterima oleh sekolah dan ada berita acara serah terima buku teks kepada sekolah. Namun pada kenyataannya ada juga penerbit/ penyedia yang meminta pembayaran saat pemesanan. Pengiriman buku teks pelajaran melalui e-katalog seharusnya membutuhkan waktu seminggu, tapi kenyataannya buku teks diterima sekolah tidak sesuai dengan jadwal yang telah ditentukan. Hasil penelitian Danuta, Krisnhoe Sukma (2017), menunjukkan bahwa pengadaan melalui e-procurement dapat mengurangi timbulnya arogansi dan kompetensi melalui transparansi yang diperoleh setelah menggunakan e-procurement. Pengadaan melalui e-katalog merupakan salah satu pengadaan e-procurement.

Penyediaan buku teks pelajaran kurikulum 2013 tahun ajaran 2017/2018 di Kabupaten Natuna dilakukan dengan dua cara, yaitu satu semester menggunakan e-katalog dan satu semester menggunakan BSE. Pembelian buku teks melalui BSE yang dilakukan secara langsung ke penyedia tidak dapat dilakukan oleh semua sekolah yang ada di Kabupaten Natuna karena tidak ada penyedia/penerbit di Kabupaten Natuna. Akibatnya sekolah harus membeli kepada distributor yang ada di Kabupaten Natuna, yaitu Toko Buku Sastra Pustaka dan Usaha Printing Verri Collection. Pada kedua distributor hanya ada display buku teks pelajaran kurikulum 2013 dan itupun tidak lengkap. Apabila sekolah akan membeli buku teks pelajaran kurikulum 
2013, maka harus memesan terlebih dahulu, karena kedua distributor tersebut akan memesan kembali ke distributor lain yang terdapat di Kota Pontianak. Pada umumnya kepala SD dan SMP membeli buku teks pelajaran kurikulum 2013 ke Toko Buku Sastra Pustaka. Sementara kepala SMA sederajat pada umumnya membeli buku teks pelajaran kurikulum 2013 ke usaha printing Verri Collection.

Harga buku teks pelajaran kurikulum 2013 yang ditawarkan oleh kedua distributor tersebut, harganya melebihi harga eceran tertinggi yang telah ditetapkan oleh Kementerian Pendidikan dan Kebudayaan. Selisih harga yang ditawarkan sekitar 20 persen dari harga eceran tertinggi pada zona IV (Kabupaten Natuna masuk dalam zona IV).

Dinas Pendidikan setempat tidak berbuat apa-apa dengan kejadian yang ada. Seharusnya Dinas Pendidikan Kabupaten Natuna memiliki tanggung jawab terhadap ketersediaan buku teks pelajaran kurikulum 2013 di wilayahnya.

\section{Kendala dalam pengadaan buku teks pelajaran kurikulum 2013 di kabupaten Natuna}

Kendala dalam pengadaan buku teks pelajaran kurikulum 2013, antara lain:

1. Kabupaten Natuna merupakan salah satu kabupaten yang termasuk dalam daerah tertinggal, terluar, dan terdepan (3T). Menurut Badan Pusat Statistik Kabupaten Natuna (2018), Kabupaten Natuna merupakan wilayah kepulauan yang terdiri dari 154 pulau, 27 pulau berpenghuni dan 127 pulau tidak berpenghuni. Tidak semua daerah di Kabupaten Natuna memiliki jaringan internet dan mendapatkan sinyal handphone (Hp), sehingga sekolah harus datang ke ibukota kecamatan atau ke Dinas Pendidikan untuk meminta bantuan memesankan buku teks pelajaran kurikulum 2013 yang pembeliannya melalui online ataupun offline.

2. Kabupaten Natuna berada di tengah lautan. sehingga harus menggunakan kapal laut atau pesawat terbang. Kota terdekat dengan Kabupaten Natuna, yaitu Kota Pontianak, Tanjung Pinang dan Batam. Transportasi ke Kabupaten Natuna dari Kota Tanjung Pinang dapat menggunakan kapal laut yang membutuhkan waktu tiga hari dengan biaya kurang lebih Rp600.000 ke atas atau kapal terbang yang membutuhkan waktu hanya 1 jam dengan harga tiket sekitar Rp1.200.000 ke atas. Sementara dari Kota Batam tidak ada kapal laut, sehingga harus menggunakan kapal terbang dengan waktu 1 jam dan harga tiket pesawat yang tidak jauh berbeda dengan harga tiket pesawat dari Kota Tanjung Pinang. Transportasi dari Kota Pontianak umumnya menggunakan kapal laut yang membutuhkan waktu dua hari dengan biaya Rp200.000 sampai Rp600.000. Oleh sebab itu, pengadaan buku teks pelajaran mengalami hambatan karena banyak penyedia yang tidak dapat memenuhi pesanan sekolah disebabkan biaya pengiriman buku teks pelajaran kurikulum 2013 yang mahal, karena dengan harga yang sudah ditetapkan Kementerian Pendidikan dan Kebudayaan keuntungan yang diterima terlalu minim.

3. Distributor buku teks pelajaran kurikulum 2013 yang ada di Kabupaten Natuna memesan buku teks kepada distributor 
yang ada di Kota Pontianak. Pengiriman buku teks tidak tepat waktu ke sekolah pemesan karena pengiriman buku teks dari Kota Pontianak ke Kabupaten Natuna menggunakan kapal laut. Sementara jadwal keberangkatan kapal laut tergantung kepada cuaca, apabila cuaca buruk maka keberangkatan akan ditunda sampai cuaca baik. Selain itu untuk bongkar muat barang dibutuhkan waktu yang tidak sebentar. Jika pelabuhan sibuk untuk masuk pelabuhan saja bisa membutuhkan waktu kurang lebih satu minggu belum termasuk bongkar muat barangnya. Oleh sebab itu, pengiriman buku teks pelajaran kurikulum 2013 mengalami keterlambatan sampai ke sekolah.

4. Harga buku yang yang ditawarkan oleh distributor melebihi HET yang sudah ditetapkan oleh Kementerian Pendidikan dan Kebudayaan, sehingga ada beberapa sekolah yang tidak dapat membeli buku untuk semua siswanya karena dananya tidak mencukupi. Jumlah buku teks pelajaran kurikulum 2013 yang tidak dapat dibeli tahun ini dapat dipenuhi pada tahun berikutnya. Sekolah terpaksa membeli karena tidak ada distributor lainnya.

\section{SIMPULAN DAN OPSI KEBIJAKAN SIMPULAN}

Pelaksanaan pengadaan buku teks pelajaran kurikulum 2013 di Kabupaten Natuna menggunakan dua mekanisme, yaitu e-katalog dan BSE. Kedua mekanisme tersebut tidak berjalan sesuai harapan sekolah dan menyulitkan sekolah karena tidak semua sekolah memiliki jaringan internet dan buku diterima sekolah tidak tepat waktu. Pengadaan buku teks pelajaran kurikulum 2013 tidak efektif dan efisien karena sekolahsekolah di Kabupaten Natuna tidak dapat menggunakan buku teks pelajaran kurikulum 2013 tepat waktu pada tahun ajaran baru dan biaya mahal.

Sumber pendanaan pengadaan buku teks Kurikulum 2013 di Kabupaten Natuna Tahun anggaran 2017 dan 2018 bersumber dari dana BOS tidak ada dari sumber lainnya. Buku teks pelajaran Kurikulum Tahun 2013 yang dibeli sesuai dengan kebutuhan sekolah, seperti buku tematik yaitu tema 1 dan tema 2 untuk siswa dan guru SD. Buku mata pelajaran seperti PPKn, Bahasa Indonesia, Bahasa Inggris, Matematika dan lainnya untuk siswa SMP, SMA dan gurunya. Selain itu ada juga sekolah yang membeli buku peminatan khususnya di SMA sesuai dengan jurusan. Namun, ada beberapa sekolah yang tidak dapat membeli buku sebanyak jumlah siswa yang ada di sekolah tersebut, karena dana BOS tidak mencukupi.

\section{OPSI KEBIJAKAN}

Penyediaan buku teks pelajaran kurikulum, 2013:

1. Untuk pemesanan buku sebaiknya dikoordinasi menjadi satu oleh Disdik atau salah satu sekolah yang internetnya mudah dalam wilayah yang sama, sehingga penyedia/penerbit dapat mengirimkan buku teks secara langsung karena ongkos kirimnya dapat ditutupi dengan banyaknya pesanan baik itu melalui e-katalog maupun BSE.

Kekuatan cara ini antara lain mempermudah sekolah-sekolah dalam mendapatkan buku teks kurikulum 2013 
dan mempermudah penyedia dalam memenuhi pesanan buku teks dari sekolah karena biaya kirimnya dapat ditutupi dari jumlah pemesanan yang banyak. Jika dikoordinasi oleh Dinas Pendidikan, sekolah tinggal memberikan data jumlah buku yang akan dibeli dan judulnya serta untuk kelas berapa. Dinas Pendidikan dapat bernegosiasi dalam masalah distribusi buku dengan penyedia/ penerbit. Misalkan untuk sekolah-sekolah yang ada di kecamatan ibukota dan sekitarnya bisa ambil langsung di kantor Dinas Pendidikan dan untuk sekolah yang berada di luar ibukota kecamatan didistribusikan oleh penyedia buku teks.
2. Penyediaan buku teks pelajaran kurikulum 2013 khusus di daerah 3T sebaiknya langsung disediakan oleh pusat, agar sekolah fokus dalam proses kegiatan belajaran mengajar. Hal tersebut dikarenakan daerah 3T pada umumnya geografisnya susah ditempuh dan biaya kirimnya mahal.

Kekuatan pola seperti ini antara lain sekolah tidak perlu susah untuk membeli buku teks pelajaran kurikulum 2013 karena akan diantar langsung oleh pusat ke sekolah. Sekolah-sekolah di daerah 3T ini memiliki geografis yang susah dijangkau sehingga butuh biaya yang besar untuk mendapatkan buku teks. Dengan bantuan pusat permasalahan itu dapat diatasi.

\section{PUSTAKA ACUAN}

Andina, Elga, 2011. Buku Digital dan Pengaturannya. Jurnal Aspirasi, Vol 2, No.1, Juni 2011, dalam http://jurnal.dpr.go.id/index.php/aspirasi/article/view/429, diunsuh tanggal 12 Oktober 2018.

Ayuningtyas, Riza dan Budiyono, 2016. Analisis Kualitas Buku Siswa Kurikulum 2013 Kelas VII Sekolah Menengah Pertama,

Badan Pusat Statistik, Kabupaten Natuna, 2018. Kabupaten Natuna Dalam Angka 2018. Kabupaten Natuna: BPS Kabupaten Natuna.

Bagus, Lorens, 1996. Kamus Filsafat. Jakarta: Gramedia.

Danuta, Krisnhoe Sukma, 2017. Crowe's Fraud Pentagon Theory dalam Pencegahan Fraud pada Proses Pengadaan melalui E-Procurement dalam http://jurnal.unswagati.ac.id/ index.php/jka/article/view/826/558, diakses 29 Agustus 2019.

Efendi, Anwar, 2009. Beberapa Catatan Buku Teks Pelajaran di Sekolah. Jurnal Pemikiran Alternatif Pendidikan Insania/Vol.14/No.2/ Mei-Agustus 2009/320-333, file://C:/ Users/Asus/Downloads/334-Article\%20Text-647-1-10-201503 04\%20(1).pdf, diunduh tanggal 12 Oktober 2018.

http://dapo.dikdasmen.kemdikbud.go.id/sp/1/310000, diunduh tanggal 6 Oktober 2018.

http://dikdasmen.kemdikbud.go.id/bse/

Hendrawanto, Yusuf, 2017. Kelayakan Buku Teks Bahasa Indonesia SMA/SMK: Analisis Kebahasaan, Isi, Penyajian, Kegrafikaam, dan Keterbacaan. Tesis: Program Studi Pendidikan Bahasa Indonesia Pascasarjana Universitas Negeri Semarang, https://lib. unnes.ac.id/27037/1/full.pdf, diakses tanggal 30 Agustus 2019. 
Ilham, Muhammad, 2009. Peranan Buku Sekolah Elektronik (BSE) Dalam Men ingkatkan Prestasi Belajar Siswa Pada Bidang Study Pendidikan Agama Islam (PAI) Di SDN Jetak Probolinggo, Skripsi: Fakultas Tarbiyah, Jurusanan Pendidikan Agama Islam, Institut Agama Islam Negeri Sunan Ampel, 2009, http://digilib.uinsby.ac.id/7818/25/ Muhammad\%20Ilham_D31304060.pdf, diakses tanggal 15 Juli 2019.

Irawan, Zaenal, Eka Sari, Maya, Umi Setyoningrum, Muthia, 2011. Analisis Implementasi Kebijakan Buku Sekolah Elektronik (BSE) Kementerian Pendidikan Nasional Di SMA Kota Yogyakarta (Studi kasus di SMAN 8 dan SMAN 9 Yogayakarta). Journal UNY, Volume VI, Nomor 1, April 2011, dalam https://journal.uny.ac.id/ index.php/pelita/ article/view/4298, diunduh 12 Oktober 2018.

Kompas, 2008. Permasalahan Buku Sekolah Sangat Kompleks dalam https://edukasi.kompas. com/read/2008/07/24/16205022/permasalahan.buku.sekolah.sangat.kompleks, diakses tanggal 29 Agustus 2019.

Moenir, AS.,.2001. Manajemen Pelayanan Umum. Jakarta: Bumi Aksara.

Novianto, Anwar, dan Mustadi, Ali, 2015. Analisis Buku Teks Muatan Tematik Integratif, Scientific Approach, dan Authentic Assessment Sekolah Dasar. Jurnal Kependidikan, Volume 45, Nomor 1, Mei 2015. Halaman 1 - 15, dalam https://journal.uny.ac.id/index. php/jk/article/view/7181, diunduh tanggal 12 Oktober 2018.

Peraturan Pemerintah Rebuplik Indonesia Nomor 32 Tahun 2013, tentang Perubahan Atas Peraturan Pemerintah Nomor 19 Tahun 2005, tentang Standar Nasional Pendidikan. Jakarta: Kementerian Hukum Dan Hak Asasi Manusia.

Peraturan Presiden Rebulik Indonesia Nomor 54 Tahun 2010, tentang Pengadaan Barang/Jasa Pemerintah. Jakarta: Kementerian Hukum Dan Hak Asasi Manusia.

Peraturan Menteri Pendidikan dan Kebudayaan Republik Indonesia Nomor 8 Tahun 2016 tentang Buku Yang Digunakan Oleh Satuan Pendidikan. Jakarta: Kementerian Hukum Dan Hak Asasi Manusia.

Peraturan Menteri Pendidikan dan Kebudayaan Republik Indonesia Nomor 1 Tahun 2018 tentang Petunjuk Teknis Bantuan Operasional Sekolah (BOS). Jakarta: Kementerian Hukum Dan Hak Asasi Manusia.

Prastowo, Andi, 2012. Panduan Kreatif Membuat Bahan Ajar Inovatif. Yogyakarta: Diva Press.

Rahmawati, Gustini, 2015. Buku Teks Pelajaran Sebagai Sumber Belajar Siswa Di Perpustakaan Sekolah SMAN 3 Bandung. Jurnal UPI Tahun 5, Volume 5, No.1 Mei 2015, dalam http://ejournal.upi.edu/index. php/edulib/article/view/2307/1601, diunduh tanggal 12 Oktober 2018.

Rahmanto, Sujari, 2019. Manajemen Pembiayaan sekolah. Lampung: CV. Gre Publishing

Sumarni, Neni, 2015. Analisis Pengelolaan Dana Bantuan Operasional(BOS) Di SMPN 6 Satap Rambah Samo dalam http://e-journal.upp.ac.id/index.php/fekon/article/view/424/452, diakses tanggal 29 Agustus 2019.

Suratni dan Jimmy Paat, 2014. Penelahaan Buku Teks Pelajaran Kurikulum 2013 Ditinjau Dari Aspek Kelayakan Isi, Penyajian, Bahasa, Dan Kegrafikaan. Jurnal Publipreneur, Vol. 2, Nomor 3, Juni 2014, ISSN: 2338-5049 dalam https:/www.academia. edu/11708949/PENELAAHAN_BUKU TEKS PELAJARAN_KURIKULUM 2013 
DITINJAU_DARI_ASPEK_KELAYAKAN_ISI_PENYAJIAN_BAHASA_DAN KEGRAFIKAAN, diakses tanggal 29 Agustus 2019.

Surya Hasnita, Siska, Sundarso, Slamet Santosa, R, 2014. Evaluasi Program Buku Sekolah Elektronik (BSE) Kementerian Pendidikan Nasional Tingkat SMA Di Kota Semarang, https://ejournal3.undip.ac.id/index.php/jppmr/article/view/4327/4182, diakses tanggal 15 Juli 2019.

Tarigan, Djago, H. G. Tarigan. 1986. Telaah Buku Teks Bahasa Indonesia. Bandung: Angkasa.

Undang-Undang Republik Indonesia Nomor 3 tahun 2017 tentang Sistem Perbukuan. Jakarta: Kementerian Hukum Dan Hak Asasi Manusia.

Yusmium, Ika, 2015. Analisis Buku Teks Mata Pelajaran Ilmu Pengetahuan Alam SMP/ MTs Kurikulum. Skripsi: Fakultas Tarbiyah dan keguruan Universitas Islam Negeri Walisongo. Semarang, 2013, dalam http://eprints.walisongo.ac.id/4553/1/113811052. pdf, diunduh tanggal 12 Oktober 2018. 